\title{
Commentary \\ Patient-level glucose reporting: averages, episodes, or something in between?
}

\author{
Susan S Braithwaite
}

University of North Carolina - Chapel Hill, Highgate, Durham, NC 27713, USA

Corresponding author: Susan S Braithwaite, sbraithw@med.unc.edu

Published: 10 April 2008

Critical Care 2008, 12:133 (doi:10.1186/cc6842)

This article is online at http://ccforum.com/content/12/2/133

(c) 2008 BioMed Central Ltd

See related research by Van Herpe et al., http://ccforum.com/content/12/1/R24

\begin{abstract}
The article by Van Herpe and colleagues in the previous issue of Critical Care describes the glycemic penalty index (GPI), which weights both hyperglycemic and hypoglycemic blood glucose measurements commensurate to their clinically significant difference from target. Although certain adverse consequences result from isolated severe hyperglycemic episodes, several specific outcomes depend upon overall hyperglycemia. In contrast, although mortality has been related epidemiologically to overall low blood glucose, specific negative outcomes may depend upon isolated episodes. Capturing both hypoglycemia and hyperglycemia in a single index will be shown to be useful if the GPI enables us to better define insulin strategies, outcomes, and targets.
\end{abstract}

In the previous issue of Critical Care, Van Herpe and colleagues describe a new method of blood glucose reporting for hospitalized patients, the glycemic penalty index (GPI) [1]. A stepped scale weights the clinical significance of differences of blood glucose (BG) from target. The GPI scale is appropriately accordioned on the hypoglycemic range and expanded on the hyperglycemic range. The relative contributions of hypoglycemia and hyperglycemia to the index may be stated separately. The authors recommend that use of the index should be combined with counting of episodes of severe hypoglycemia. The index, capturing both overall hyperglycemia and hypoglycemia, could permit analysis of the ability of an algorithm to control between-patient glycemic variability.

In the evaluation of glycemic control, the measures that are simplest to ascertain are the average and standard deviation, using the BG as the unit of observation [2]. In the Leuven, Belgium surgical intensive care unit, the standard deviations in intensively and conventionally treated groups was 19 and $33 \mathrm{mg} / \mathrm{dL}$, respectively [2]. It could have been asked whether the greater BG variability in the conventionally treated group reflected the contribution of a hyperglycemic subgroup. Until a second report was issued referring to control at the patient level, within the conventionally treated group even the relationship between hyperglycemia and mortality rate was unclear [3].

In order to evaluate patient outcomes, there is no substitute for reporting on the patient as the unit of observation. A key question is whether patient outcomes relate to overall hyperglycemia during a critical timeframe or to specific episodes of severe hyperglycemia. The answer, predicated upon the mechanism of harm, could depend upon what outcome is being studied. Single episodes of severe hyperglycemia, such as the in-hospital development of diabetic ketoacidosis or hyperglycemia-associated dehydration, may result in specific consequences, such as dialysis fistula thrombosis, readmission to a critical care unit, or treatmentrelated pulmonary edema. The association of single episodes with outcomes was recognized by Stagnaro-Green and colleagues [4]. Furnary and colleagues [5], capitalizing upon a critical window of time in the postoperative interval following heart surgery, have reported on outcomes in relation to the "3-day BG," each value representing a patient's 3-day average of postoperative BG measurements [5]. Recent literature supports the importance of overall prevention of hyperglycemia, at least during critical windows of time, with respect to survival and morbidities such as sepsis, renal failure, duration of ventilator dependency, or transfusion requirement $[2,6]$. Unfortunately, we have no simple measure comparable to the $\mathrm{A} 1 \mathrm{C}$ by which the shortterm inpatient overall glycemic control of an individual may be described.

Although hypoglycemia might simply reflect severity of comorbidities, the correlation between hypoglycemia and mortality of hospitalized patients is well known [7]. Evidence

$\mathrm{BG}=$ blood glucose $; \mathrm{GPI}=$ glycemic penalty index. 
from a mixed intensive care unit suggests that hypoglycemia is an independent predictor of mortality [8]. Among groups of patients having myocardial infarction or congestive heart failure, observational patient-level data suggest that when mortality is considered as a function of overall BG concentration, there may be a J-shaped curve, such that patients having the lowest and the highest averages experience outcomes worse than those having intermediate range $B G$ control $[9,10]$. Is there a plausible mechanism by which modest overall reduction of average BG might cause harm, and if so, what specific harm is caused? Alternatively, is harm a consequence of isolated episodes of severe hypoglycemia, to which the population having lower average $\mathrm{BG}$ is more vulnerable?

In the literature concerning strict glycemic control, serious or fatal consequences of hypoglycemia occasionally are reported [11,12]. However, even when severe hypoglycemia is reported, sublethal permanent neurological injury seldom is described [13,14]. If a patient-level metric relied only upon BG averaging methods, isolated episodes of severe hypoglycemia could be overlooked that had resulted in altered function with respect to the activities of daily living or reduction of intellectual capacity. A superior method of ascertainment is to count such episodes and describe their consequences [15].

Application of the GPI index is cumbersome, such that other centers may have difficulty in adopting the method; therefore, the measure may remain unfamiliar. Perhaps overall hyperglycemia and discrete episodes of hypoglycemia ought not to be captured by the same metric. An extra mental step is needed to quantify the contribution of hypoglycemia and hyperglycemia as a fraction of the total value of the index. The mathematical strategy of the GPI avoids overemphasis on outlying results. Multiple small episodes of hypoglycemia, none having clinical impact, might be weighted equally to one severe life-changing episode. Analysis of episodes of severe hypoglycemia should complement the use of the GPI, as the authors acknowledge. With that caveat, can a single measure sum up patient risk for a variety of outcomes that might be related to glycemic control? We await evidence that the GPI will improve upon our ability to define glycemic targets and predict clinical outcomes.

\section{Competing interests}

SSB serves as a consultant for Hospira, Inc.

\section{References}

1. Van Herpe $T$, De Brabanter J, Beullens M, De Moor B, Van den Berghe G: Glycemic penalty index for adequately assessing and comparing different blood glucose control algorithms. Crit Care 2008, 12:R24.

2. van den Berghe $G$, Wouters $P$, Weekers F, Verwaest $C$, Bruyninckx F, Schetz M, Vlasselaers D, Ferdinande P, Lauwers P, BouilIon R: Intensive insulin therapy in critically ill patients. $N$ Engl J Med 2001, 345:1359-1367.

3. Van den Berghe G, Wouters PJ, Bouillon R, Weekers F, Verwaest C, Schetz M, Vlasselaers D, Ferdinande P, Lauwers P: Outcome benefit of intensive insulin therapy in the critically ill: Insulin dose versus glycemic control. Crit Care Med 2003, 31:359366.

4. Stagnaro-Green A, Barton MK, Linekin PL, Corkery E, deBeer K, Roman SH: Mortalilty in hospitalized patients with hypoglycemia and severe hyperglycemia. Mount Sinai J Med 1995 62:422-426.

5. Furnary AP, Gao G, Grunkemeier GL, Wu Y, Zerr KJ, Bookin SO, Floten HS, Starr A: Continuous insulin infusion reduces mortality in patients with diabetes undergoing coronary artery bypass grafting. J Thorac Cardiovasc Surg 2003, 125:10071021.

6. Krinsley JS: Effect of an intensive glucose management protocol on the mortality of critically ill adult patients. Mayo Clin Proc 2004, 79:992-1000.

7. Kagansky N, Levy S, Rimon E, Cojocaru L, Fridman A, Ozer Z, Knobler H: Hypoglycemia as a predictor of mortality in hospitalized elderly patients. Arch Intern Med 2003, 163:1825-1829.

8. Krinsley JS, Grover A: Severe hypoglycemia in critically ill patients: risk factors and outcomes. Crit Care Med 2007, 35: 2262-2267.

9. Eshaghian S, Horwich TB, Fonarow GC: An unexpected inverse relationship between $\mathrm{HbA1c}$ levels and mortality in patients with diabetes and advanced systolic heart failure. Am Heart $J$ 2006, 151:91.

10. Kosiborod M, Inzucchi SE, Krumholz HM, Xiao L, Jones PG, Fiske S, Masoudi FA, Marso SP, Spertus JA: Glucometrics in patients hospitalized with acute myocardial infarction: defining the optimal outcomes-based measure of risk. Circulation 2008, 117:1018-1027.

11. Bhatia A, Cadman B, Mackenzie I: Hypoglycemia and cardiac arrest in a critically ill patient on strict glycemic control. Anesth Analg 2006, 102:549-551.

12. Scalea TM, Bochicchio GV, Bochicchio KM, Johnson SB, Joshi M, Pyle A: Tight glycemic control in critically injured trauma patients. Ann Surg 2007, 246:605-610; discussion 10-12.

13. Van den Berghe G, Wilmer A, Hermans G, Meersseman W, Wouters PJ, Milants I, Van Wijngaerden E, Bobbaers $\mathrm{H}$, Bouillon $\mathrm{R}$ : Intensive insulin therapy in the medical ICU. $N$ Engl J Med 2006, 354:449-461.

14. Brunkhorst FM, Engel C, Bloos F, Meier-Hellmann A, Ragaller M, Weiler N, Moerer O, Gruendling M, Oppert M, Grond S, Olthoff D, Jaschinski U, John S, Rossaint R, Welte T, Schaefer M, Kern P, Kuhnt E, Kiehntopf M, Hartog C, Natanson C, Loeffler M, Reinhart K; German Competence Network Sepsis (SepNet): Intensive insulin therapy and pentastarch resuscitation in severe sepsis. N Engl J Med 2008, 358:125-139.

15. Varghese P, Gleason V, Sorokin R, Senholzi C, Jabbour S, Gottlieb JE: Hypoglycemia in hospitalized patients treated with antihyperglycemic agents. J Hosp Med 2007, 2:234-240. 